\title{
The Predictive Value of Vital Sign Patterns for Morbidity in Pregnancy: A Retrospective Cohort Study
}

\author{
Adina Kern-Goldberger ${ }^{1}$, Julie Ewing ${ }^{2}$, Melanie Polin ${ }^{3}$, Mary DAlton ${ }^{4}$, Alex Friedman \\ $(\mathrm{USA})^{5}$, and Dena Goffman ${ }^{2}$ \\ ${ }^{1}$ Hospital of the University of Pennsylvania \\ ${ }^{2}$ NewYork-Presbyterian Hospital \\ ${ }^{3}$ Columbia University Irving Medical Center \\ ${ }^{4}$ Columbia University \\ ${ }^{5}$ Columbia University College of Physicians and Surgeons
}

October 23, 2020

\begin{abstract}
Objective. This study examined the predictive ability of established Maternal Early Warning systems (MEWS) for different types of maternal morbidity, in order to discern an optimal early warning system. Design. Retrospective cohort study. Setting. Four-hospital urban academic system. Population. All patients admitted to the obstetric services of this hospital system in 2018. Methods. All patient vital signs were collected and three sets of published MEWS criteria were evaluated in relation to maternal morbidity. The test characteristics of each MEWS, as well as for heart rate, blood pressure, and oxygen saturation individually and in different combinations were compared. Main Outcome Measures. Maternal morbidity, defined as a composite of hemorrhage, infection, acute cardiac disease, and acute respiratory disease, ascertained from informatics and administrative data. Results. Of 14,597 obstetric admissions, 2,451 patients experienced composite morbidity (16.8\%). The sensitivities (15.3\% - $64.8 \%)$, specificities $(56.8 \%-96.1 \%)$, and positive predictive values $(22.3 \%-44.5 \%)$ of the three MEWS criteria ranged. Of patients with any morbidity, $28 \%$ met criteria for the most liberal vital sign combination, while only $2 \%$ met criteria for the most restrictive parameters, compared to $14 \%$ and $1 \%$ of patients without morbidity, respectively. Sensitivity of all vital sign combinations was low (maximum 28.2\%), while specificity ranged from $86.1-99.3 \%$. Conclusions. Though all MEWS criteria demonstrated poor sensitivity for maternal morbidity, permutations of the most abnormal vital signs have high specificity, suggesting that MEWS may be better implemented as a trigger tool to target more sensitive screening techniques for maternal morbidity.
\end{abstract}

\section{Hosted file}

Vital Signs Manuscript_BJOG.pdf available at https://authorea.com/users/369778/articles/ 488570-the-predictive-value-of-vital-sign-patterns-for-morbidity-in-pregnancy-aretrospective-cohort-study

\section{Hosted file}

Table 1.pdf available at https://authorea.com/users/369778/articles/488570-the-predictivevalue-of-vital-sign-patterns-for-morbidity-in-pregnancy-a-retrospective-cohort-study

\section{Hosted file}

Table 2.pdf available at https://authorea.com/users/369778/articles/488570-the-predictivevalue-of-vital-sign-patterns-for-morbidity-in-pregnancy-a-retrospective-cohort-study 


\section{Hosted file}

Table 3.pdf available at https://authorea.com/users/369778/articles/488570-the-predictivevalue-of-vital-sign-patterns-for-morbidity-in-pregnancy-a-retrospective-cohort-study

\section{Hosted file}

Table 4.pdf available at https://authorea.com/users/369778/articles/488570-the-predictivevalue-of-vital-sign-patterns-for-morbidity-in-pregnancy-a-retrospective-cohort-study

\section{Hosted file}

Table 5.pdf available at https://authorea.com/users/369778/articles/488570-the-predictivevalue-of-vital-sign-patterns-for-morbidity-in-pregnancy-a-retrospective-cohort-study

\section{Hosted file}

Table 6.pdf available at https://authorea.com/users/369778/articles/488570-the-predictivevalue-of-vital-sign-patterns-for-morbidity-in-pregnancy-a-retrospective-cohort-study

\section{Hosted file}

Table 7.pdf available at https://authorea.com/users/369778/articles/488570-the-predictivevalue-of-vital-sign-patterns-for-morbidity-in-pregnancy-a-retrospective-cohort-study

\section{Hosted file}

Table 8.pdf available at https://authorea.com/users/369778/articles/488570-the-predictivevalue-of-vital-sign-patterns-for-morbidity-in-pregnancy-a-retrospective-cohort-study

\section{Hosted file}

Table 9.pdf available at https://authorea.com/users/369778/articles/488570-the-predictivevalue-of-vital-sign-patterns-for-morbidity-in-pregnancy-a-retrospective-cohort-study

\section{Hosted file}

Table 10.pdf available at https://authorea.com/users/369778/articles/488570-the-predictivevalue-of-vital-sign-patterns-for-morbidity-in-pregnancy-a-retrospective-cohort-study

\section{Hosted file}

Figure 1.pdf available at https://authorea.com/users/369778/articles/488570-the-predictivevalue-of-vital-sign-patterns-for-morbidity-in-pregnancy-a-retrospective-cohort-study

\section{Hosted file}

Figure 2.pdf available at https://authorea.com/users/369778/articles/488570-the-predictivevalue-of-vital-sign-patterns-for-morbidity-in-pregnancy-a-retrospective-cohort-study

\section{Hosted file}

Figure 3.pdf available at https://authorea.com/users/369778/articles/488570-the-predictivevalue-of-vital-sign-patterns-for-morbidity-in-pregnancy-a-retrospective-cohort-study 